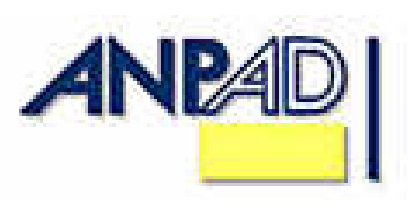

Available online at

http://www.anpad.org.br/bar

BAR, Curitiba, v. 5, n. 3, art. 2, p. 193-209,

July/Sept. 2008

\title{
Services Offshoring and Its Strategic Effects on Value Chains
}

\author{
Paulo Roberto Gião * \\ E-mail address: giao@usp.br \\ Faculdade de Economia, Administração e Contabilidade - Universidade de São Paulo \\ São Paulo, SP, Brazil.
}

\author{
Moacir de Miranda Oliveira Júnior \\ E-mail address: mirandaoliveira@usp.br \\ Faculdade de Economia, Administração e Contabilidade - Universidade de São Paulo \\ São Paulo, SP, Brazil.
}

\section{Eduardo Pinheiro Gondim de Vasconcellos}

E-mail address: epgdvasc@usp.br

Faculdade de Economia, Administração e Contabilidade - Universidade de São Paulo

São Paulo, SP, Brazil.

\begin{abstract}
This article's main objective is to examine some known management theories under the offshoring point of view. It detaches some factors in existing theories and how they can be at risk in an increasing offshoring of services processes. In the absence of more systematic studies about the effects of offshoring over value chain and core competencies imprecise borders and definitions, we try to interpret them in a holistic manner and stimulate discussions in a new area of study rather than to provide definitive general conclusions. The methodological aspects mainly concerning the offshoring bibliography are very impressive, especially since 2000 . There seems to be a new trend appearing, like a wedge between strategy and international business theories, or that at least complements these theories. The analysis presented in this paper is offered as an aid to systematic investigation involving value chains, core competencies, innovations and the accelerated process of offshore outsourcing of services. Some preliminary evidence showed countries and companies in good conditions to improve their participation in the international market. The internationalization of these new firms from emerging countries and their learning process may need extension to existing theories, at least from the perspective of emerging and in the developing world.
\end{abstract}

Key words: offshoring; value chain; core competencies; internationalization.

Received 09 October 2007; received in revised form 01 July 2008.

Copyright (C) 2008 Brazilian Administration Review. All rights reserved, including rights for translation. Parts of this work may be quoted without prior knowledge on the condition that the source is identified.

*Corresponding author: Paulo Roberto Gião

Rua Maria Cândida R. Peres, 56, São João da Boa Vista, SP, 13874-430, Brazil. 


\section{INTRODUCTION}

Worldwide, there is a rising need for highly skilled technology professionals. These factors have increased corporations' reliance on their outsourced technology service providers and are likely to continue to drive future growth for outsourced technology services. Customers are increasingly demanding improved products and services with shorter delivery times and lower prices. To address these needs, corporations are focusing on their core competencies and using outsourced technology service providers to help improve productivity, develop new products, conduct R\&D activities, reduce business risks and manage operations more effectively. Gottfredson, Puryear and Phillips (2005, p. 132) stated that:

(...) outsourcing is becoming so sophisticated that even core functions like engineering, $R \& D$, manufacturing, and marketing can - and often should - be moved outside. And that, in turn, is changing the way firms think about their organizations, their value chains, and their competitive positions.

Effective use of offshore technology services offers a variety of benefits, including lower total cost of ownership of IT infrastructure, lower labor costs, improved quality and innovation, faster delivery of technology solutions and more scheduling flexibility. Linder (2004, p. 52) added that

Outsourcing isn't what it used to be. When executives began outsourcing substantial portions of their operations more than a decade ago, they did it due to several reasons. Frequently, the purpose was to offload activities they declared to be non-core in order to cut costs and improve strategic focus. (...) Today, however, companies are looking outside for help for more fundamental reasons - to facilitate rapid organizational change, to launch new strategies and to reshape company boundaries. In doing so, they are engaging in transformational outsourcing: partnering with another company to achieve a rapid, substantial and sustainable improvement in enterprise-level performance.

The changes reported above are influencing business strategies, business plans and, of course, the value chain of many organizations around the world. The main objective of this paper is to examine some known management theories from the offshoring point of view. It detaches some factors in existing theories and how they can be under risk in an increasing offshoring of services process. In the absence of more systematic studies into the effects of offshoring over value chain and core competencies, imprecise borders and definitions, we try to interpret them in a holistic manner and stimulate discussions in a new area of study rather than to provide definitive general conclusions. In a similar theoretical approach, Vasconcelos and Cyrino (2000) analyzed the convergence between business strategy and organizational theory and found a promising research opportunity for both disciplines.

In the recent past, it was felt that it was impossible to outsource some of these activities, such as R\&D and innovation, because of their importance to the company, but many things are changing in the business environment, spurred by the pursuit of better financial results and by a more fragmented value chain, down to the level of identifying value chain sub-links.

This paper also has as a second objective: to identify in the literature Brazilian organizations that provide offshoring services to other countries. A recent survey of call centers showed that some organizations are providing services such as customer care, technical support and back-offices. However, this was merely the beginning of an informal or, in some cases, formal identification of companies able to provide these kinds of services. An attempt will be made to answer the following questions: what is the profile of Brazilian organizations in this line of business? How many companies are providing offshoring services? What is necessary to provide offshoring services? Do they only cover low cost services or are value-adding services being provided as well where Brazilian companies are concerned? 
The methodological aspects considered mainly the offshoring bibliography that is so impressive, especially since 2000. There seems to be a new trend appearing, like a wedge between strategy and international business theories, or that at least complements these theories. Many citations were quoted as written by their original authors, in order to safeguard their opinions, interpretations and results and to avoid any potential misunderstanding of ours.

\section{BRIEF HISTORY AND DEFINITIONS}

Robinson and Kalakota (2004) stated that the origin of offshore outsourcing can be credited to Ronald Coase who, in 1937, in his work 'The Nature of the Firm' explained that firms choose what to produce and what needs to be hired or obtained from outside companies.

Thus, outsourcing is not a new idea. However, the outsourcing process was related to the manufacturing of goods by inshore or offshore third-party companies from the $60 \mathrm{~s}$ to the $80 \mathrm{~s}$. The trend's difference, or the complement to it, was the growing inclusion of services, and not only manufacturing-related activities, in the outsourcing process. According to Farrel (2004), "in the 1980s, manufacturers based in North America, Europe, and Japan built plants and hired workers in low-wage countries, then exported the finished goods back home. (...). Now, globalization is beginning to transform the service industry" (p. 17).

In line with this evolution, Ramanujan and Sandhyia (2006, p. 51) felt that

(...) as the 1990s market matured, most of the companies were routinely outsourcing their information systems functions as well as other functions like finance and taxation, business process units, call centers and other important function which were considered as taboo in initial stages.

The offshoring of services, particularly of business services, is a relatively recent phenomenon that first appeared in the 1990s. Because of this novelty factor, headline news tends to cover mainly the offshoring of call centers, back-office data processing, software development and R\&D (Sako, 2005, p. 8).

Bardhan and Kroll (2003, pp. 1-2) felt there were two outsourcing waves in the U.S. market, the first regarding manufacturing and the second concerning white collar jobs. The foreign outsourcing of U.S. production and the associated loss of blue-collar jobs in many industries is attributed to the globalization of activities for offshore production of intermediate inputs, usually in low-cost developing countries, such as Taiwan, China, South Korea and Malaysia. However, the software sector was the first in the services field to transfer significant white collar activity abroad, especially to India. The Internet's rapid dissemination, the transnational networks set up by immigrants in the U.S., and the deregulation of emerging market economies set the stage for the outsourcing boom of the 1990s. The second wave of major manufacturing jobs outflow occurred in the late 1990's, chiefly driven by the high-tech sector.

Several major differences distinguish services outsourcing from the preceding wave of manufacturing jobs outsourcing. It is structurally simpler to outsource services than manufacturing, in terms of resources, space and equipment. Thus, services outsourcing can be implemented much more quickly. However, one should be aware that the occupational mix of a sector may determine its vulnerability to Business Process/Services Outsourcing [BPO/BSO]; in some circles it is said that any job that involves mostly "... sitting at a desk, talking on the phone and working on a computer..." is a job potentially at risk (Bardhan \& Kroll, 2003, p. 4).

Nevertheless, there appears to be no consensus as to the definition of outsourcing. For instance, Patki and Patki (2007) informed that the Institute of Electrical and Electronics Engineers [IEEE] and 
Association of Computing Machinery [ACM] use outsourcing and offshoring interchangeably. Grossman and Rossi-Hansberg (2006) also encountered this confusing interchangeability of words.

Robinson and Kalakota $(2004$, p. 3) presented a large number of examples that illustrate offshore outsourcing and define offshoring as the migration of part or all of the entire value chain to a low-cost location. They add that offshoring hinges on cost management through labor and skill arbitrage. It depends on the dramatic advances in telecommunications that have made it possible to establish backoffice operations in a variety of locations, thus benefiting from significantly lower labor costs.

The above definitions involve different approaches to these expressions. Excluding the firm's core business, geographical aspects, activities, occupations, the pursuit of cost reduction, better quality and collar color are all used (in an attempt) to define offshoring, but as one can see, no consensus has been reached.

A modest search in the Proquest ${ }^{\circledR}$ database using the outsourcing and offshoring words in the abstract field results in finding them mentioned in all documents, as shown in Table 1. It is interesting to note that the expression outsourcing has existed for far longer than the expression offshoring, which first appeared only in 2002 in the Wall Street Journal, in an article about offshoring IT services to India.

Table 1: Search for the Words Offshoring and Outsourcing in the Proquest ${ }^{\circledR}$ Database

\begin{tabular}{|c|c|c|c|c|}
\hline Year & Offshoring & Outsourcing & Both & Only Offshoring \\
\hline 2000 & 0 & 918 & 0 & \\
\hline 2001 & 0 & 1155 & 0 & \\
\hline 2002 & 1 & 1261 & 1 & First time apperance \\
\hline 2003 & 36 & 1437 & 15 & 21 \\
\hline 2004 & 314 & 2047 & 119 & 195 \\
\hline 2005 & 192 & 1860 & 78 & 114 \\
\hline 2006 & 196 & 1626 & 84 & 112 \\
\hline 2007 & 26 & 241 & 10 & 16 \\
\hline
\end{tabular}

Source: the authors.

Whereas offshoring first appeared in 2002, outsourcing was mentioned 1,261 times that year. Curiously, both peaked in 2004, which was also when offshoring acquired a life of its own, as the column Only Offshoring shows. Additionally, Abramovsky, Griffith and Sako (2004) proposed, as shown in Figure 1, a scheme for differentiating all supply chain possibilities regarding inshore and offshore activities. Horvitz (2004) from McKinsey used the same matrix.

Figure 1: Corporate Boundary and Location Decision

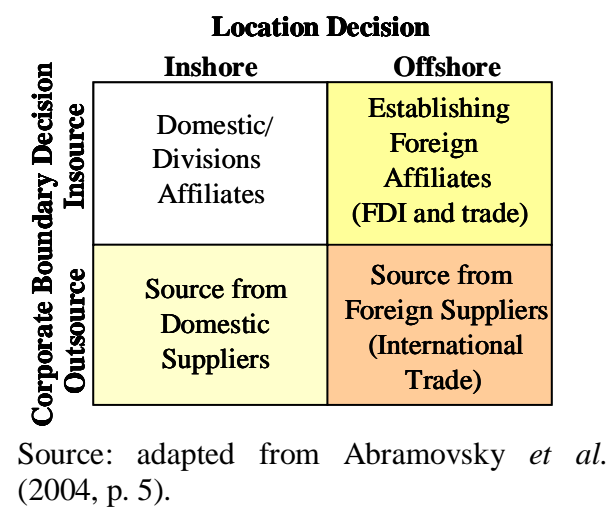

Our proposed adapted definitions are based on corporate boundaries and location, regardless of the different approaches used in the definitions above. Regardless of the reasons identified by other authors (economic, type of occupation, low or high complexity), our focus is based on location and 
corporate boundaries. Offshore outsourcing (which we will henceforth refer to as offshoring) occurs when the outsourcing company hires an entirely different organization in another country. Offshore insourcing, on the other hand, happens when a company's foreign subsidiary is hired by the former. Simple outsourcing occurs when a company is hired in the same country; whereas insourcing occurs when the activity in question is carried out internally by the same company in the same country.

\section{EVOLUTION AND STAGES}

Based perhaps on the distinction proposed by Prahalad and Hamel (1990) between core and noncore competencies and/or the cost leadership management strategies proposed by Porter (1998), organizations first started outsourcing part of their business to third-party providers but, thanks to the globalization process, advanced to not only outsourcing, but also offshoring some activities in order to maintain or acquire further competitive advantages over new competitors from anywhere in the world.

Porter (1990) also presented his diamond analysis of the competitive advantage of nations. Competitive advantage, according to him, concerns the ability of a nation's firms to use their locationbound resources to compete successfully in international markets (Reid, 2003). Through his diamond model, Porter (1990) showed how a nation is or can become competitive in international business.

Lynn and Salzman (2005, p. 2) found

that the organizational change that led to corporate restructuring in the 1990s shifted the conceptual framework of what constitutes a firm and, combined with technology and population shifts, has become a disjunctive or qualitatively new phase in organizational form and globalization.

Feenstra and Hanson (1996, p. 1) could be considered visionaries regarding the fragmentation of production into discrete activities which are then allocated across countries and what should happen in the future:

(...) [fragmentation of production] has received little attention in the literature. If firms respond to import competitive advantages from low-wage countries by moving non-skill-intensive activities abroad, then trade will shift employment toward skilled workers within industries. (...) If our outsourcing hypothesis is correct, an increase in outsourcing should be associated with the increase in the relative demand for skilled labor in all time periods.

Events that transpired during the intervening decade of the 1990s enhanced the ability of other countries to export services, particularly in the field of IT, to the United States and other developed countries (e.g., the United Kingdom). One such event was the Y2K crisis: U.S. firms, in response to a tight supply of computer programmers in the late 90s, turned to companies principally located in India to do all the fixing needed to avert problems with computer systems by the time 2000 arrived; the domestic firms that used these programmers reportedly were pleased with the quality of their work. Another event was the educational systems of foreign nations producing an abundant supply of well educated, sometimes English speaking graduates. In some cases, the number of persons with IT and accounting skills has exceeded the immediate needs of their local economies (e.g., China, Eastern Europe, India, and the Philippines). Furthermore, because English is the computer industry's language regardless of country, IT services can be provided by a wide array of non-English speaking, comparatively low wage nations (e.g., Argentina, Brazil, Bulgaria, China, the Czech Republic, Hungary, Jordan, Lithuania, Mexico, Slovenia, Russia, and Ukraine) (Levine, 2004). Gupta and Mukherji (2007, p. 4) voiced the following warning with regard to the transfer of knowledge:

The outsourcing of professional services requires firms to transfer knowledge via formal and informal channels within their organizations, as well as to establish and preserve knowledge 
repositories both for offshore teams to come up to speed on new tasks and for inshore teams to learn what is being done offshore.

A recent Bain survey (Gottfredson et al., 2005, p. 133) of large and medium-sized companies reported that $82 \%$ of large firms in Europe, Asia and North America have outsourcing arrangements of some kind, while $51 \%$ use offshore outsourcers.

A summary of the drivers of this rapid offshore outsourcing growth is presented by Robinson and Kalakota (2004, p. 5): continuous cost pressure on U.S. and European companies; rapid reduction of communication and computing costs; dramatic improvements in the reliability and functionality of the Internet; more offshore suppliers with better capabilities; high-quality inshore suppliers offering offshore services; access to low-cost, high-quality employees, especially for labor-intensive tasks; and a business model for offshoring that has been proven successful by pioneers such as GE and American Express. Similar results were found by Prado and Takaoka (2002) studying the outsourcing of software development. The authors identified some important drivers for this process: cost reduction, access to knowledge and technology, routine activities, seasonal works and the high degree of customization.

If this poses a threat to some companies and countries, on the other hand it provides opportunities for other enterprises and nations. Thus, a key difference between domestic and offshore outsourcing is that none of the jobs that are contracted out remain available to U.S. workers when employers send the work to companies located overseas (Levine, 2004). In the last five years, many companies in North America and Europe have experimented with this strategy [offshoring], hoping to reduce costs, become more efficient, and gain a little strategic advantage. (...) In early 2005, both the Boston Consulting Group and Gartner predicted that $50 \%$ of the offshoring contracts that companies in North America had signed between 2001 and 2004 would fail to meet expectations (Aron \& Singh, 2005). However, the authors add: "don't misunderstand; smart companies have gained strategic advantage by offshoring processes". Atkinson $(2004$, p. 1) reported the threat of offshoring in United States:

The offshoring panic, meanwhile, has triggered a spate of ill-conceived legislation aimed at punishing companies that send jobs overseas. At least 35 states have proposed laws aimed at preventing state funds from going to companies doing work overseas, either directly or through subcontractors. At least six states have issued requests for proposals that require the work to be performed in this country. And the 2004 federal budget contained provisions prohibiting the federal government from awarding certain contracts to companies that perform the work overseas.

Some cases are being reported as failing the offshoring process, at least in part. UK bank Lloyds TSB is about to become the latest company to return outsourced call center work to the UK. The bank has commented that, as a result of a new automated answering service, its Mumbai, India call center, which had been used as an overflow for UK call centers since 1994, is no longer necessary. According to the bank, all calls will now be handled by Lloyds TSB's 10 UK contact centers, while the Mumbai center's staff of 180 will be redeployed to handle back office processing (Datamonitor, 2007). Dell, for example, has chosen to return some customer service operations to the United States from India because corporate customers protested against handoffs (Karmarkar, 2004).

However, opportunities can be identified. Offshore providers of outsourced services offer vital and sometimes distinctive skills that are available in developed countries only at much higher cost, if at all (Hagel, 2004). Oracle Corporation's Indian subsidiary initially performed low-end routine tasks such as the maintenance of legacy applications; gradually, however, it became an integral part of a team involved in developing the Universal Server - Oracle's flagship database product (Gupta \& Mukherji, 2007).

This shows that the offshoring process can be a strategic success or failure. However, is this not the case, as well, when one tries to win new markets, launch new products, internationalize a company or 
establish a merger? Risk and success factors are always at play and the secret is how to manage the business so as to become successful.

\section{EfFects UPON the VAlue Chain}

Value chain analysis allows the firm to understand which parts of its operations create value and which do not. "What should a firm do about primary and support activities in which its resources and capabilities are not a source of core competence and, hence, of competitive advantage? Outsourcing is one solution to consider" (Hitt, Ireland, \& Hoskinsson, 2007, p. 93).

Most companies create a major portion of their incremental value and draw their real competitive advantage from relatively few activities, which are generally services (Quinn, Doorley, \& Paquette, 1990). In addition, the authors add: "At each stage, technology has increased the relative power of services to the point where they dominate virtually all companies' value chains". Quinn et al. (1990, p. 79) describe what is happening in organizations:

The process begins by redefining what the company really does. Most companies primarily produce a chain of services and integrate these into a form most useful to certain customers. (...) The vast majority of their systems costs, value-added, profits, and competitive advantage grow out of services activities. (...) Value is added primarily by service activities.

The value chain can be explained and explored in many ways, depending on the focus of the analysis. Recently, some radical perspectives have been proposed: to fragment the value chain into as many parts as possible. This obviously has an impact on the chain. If one looks at the value chain (Figure 2) with its building blocks, imagines a generic firm and thinks of it as a set of systems, then how many subsystems can a system be fragmented into? In which system(s) lie(s) its core competence? Supposing the core competence is in the operations link, one might ask: does the core competence involve the entire operations link or only a part (parts) of it? If the answer is parts of it, other operation link subsystems could be outsourced.

In addition, the value chain should be seen as a dynamic model. Moori and Zilber (2003) in a survey with 100 companies found that there is a movement of activities among primary and support tasks and vice-versa as a fluidic perspective.

Another question is: where do innovations occur in this firm? Innovations can happen in any system of the chain, probably; therefore the ensuing question would be: do innovations happen in all systems or in some subsystems of this system? If the answer is in some subsystems, the others can be outsourced. However, is this firm recognized for its innovations? If it is, subsystems can contain core competencies, if it is not, why not outsource to best-in-class companies around the world?

This is a simple way to think strategically about the value chain in connection with outsourcing (and offshoring), to identify possible opportunities and, of course, to identify the real core competencies and protect them. 
Figure 2: Fragmented Value Chain

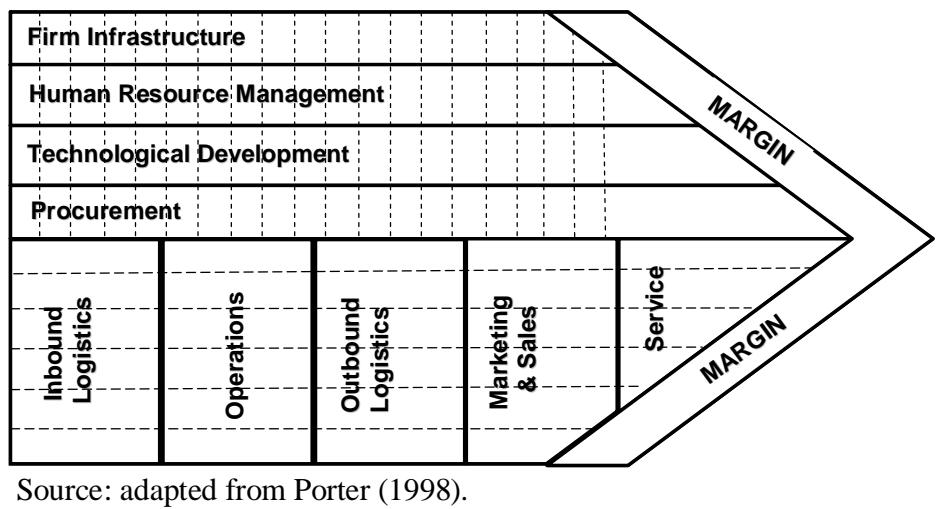

Some of them are analyzed below and are found in the recent literature. First, what are really the core competencies? Second, can offshoring lead to innovation? And third, can offshoring be an opportunity for the business?

\section{The Core of the Core Competencies}

According to Prahalad and Hamel (1990), at least three criteria can be applied to identifying a company's core competencies. First, a core competence provides potential access to a wide variety of markets; second, a core competence should make a significant contribution to the perceived customer benefits of the end product; and third, a core competence should be difficult for competitors to imitate. Quinn (1999, p. 11) added:

Core competencies are not products or those things we do relatively well; they are those activities usually intellectually-based service activities or systems - that the company performs better than any other enterprise. They are the sets of skills and systems that the company does at best in world levels and through which a company creates uniquely high value for customers.

Figure 3 shows Quinn's point of view, according to which there are non-core, essential but non-core, and core competencies.

Figure 3: Core, Essential but Non-Core, and Non-Core Competencies

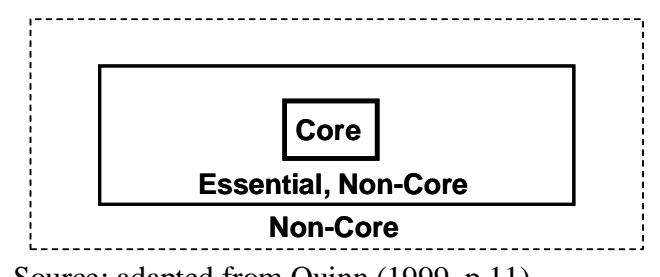

Source: adapted from Quinn (1999, p 11).

Quinn (1999), interpreting the figure, said that non-core activities can be outsourced. Essential but non-core activities, on the other hand, must be studied carefully, because non-core competencies can act as a protective shield for core competencies. Finally the core competencies or best-in-world activities should remain in-house. 
Unfortunately, the true nature of these core capabilities is usually obscured by the tendency of organizations to think about their strengths in terms of products, rather than of activities or services, and by each functional group's need to see itself as the source of strategic strength. The key point is that a few selected activities should drive strategy. Knowledge bases, skill sets and service activities are what generally lead to continued added value and competitive advantage (Quinn et al., 1990).

Perhaps neither Prahalad and Hamel nor Quinn realized that core competencies should always be kept in-house. However, Lynn and Salzman $(2005$, p. 2) perceived this when they said "in the latest phase of globalization, some firms are dispersing their core competencies around the globe, seemingly tempting fate by locating them in countries that may build on those activities to launch possible future competitors". Some are even outsourcing R\&D and design activities to firms in Taiwan and other countries. Is this just the next evolutionary step in organizational restructuring that continues a decades-old trend, leading to greater efficiency in the triad economies, as well as creating new economic opportunities for those hosting the new activities? Or is it becoming something entirely new?

In a more specific bibliography about offshoring, Vashistha and Vashistha (2006, p. 133) presented a figure similar to Quinn's, but more aggressive, involving the penetration of the offshoring trend all the way to the center of the picture, going through all layers, until reaching the core competencies (Figure 4).

In agreement with this, Lislie (2003), after Gottschalk and Solli-Saether (2006), suggested that a core competency can be outsourced. He argued that the core competency of a private equity group is analyzing the business strategy of acquisition targets. His main arguments for the outsourcing of core competency in this case are conflicting priorities and operating costs.

Figure 4: Defining the Offshorable Processes

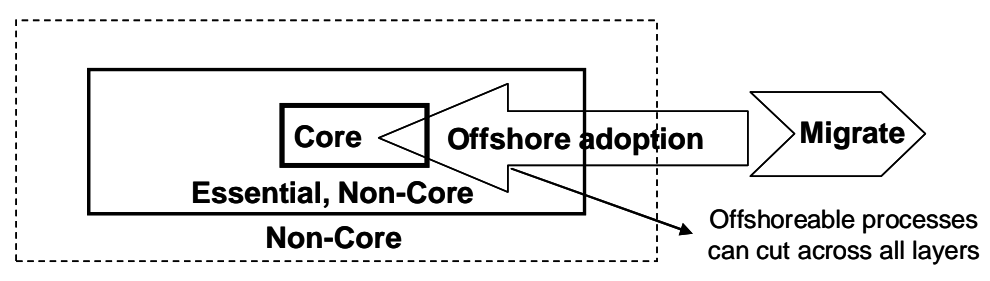

Source: adapted from Vashistha and Vashistha (2006, p. 133).

If in many cases $R \& D$ and design can be outsourced, what exactly are the core competencies of an organization? Gottfredson et al. (2005) proposed a framework for capability sourcing according to which the first step is to identify the components of the business that represent the core of the core. If this is true, perhaps the core in Figure 5 can be seen not as a solid core, as proposed by Quinn, but as a porous core with space between the core competencies because some of them can be outsourced!

In a more systematic way, Fleury and Fleury (2002) in their study of individual and organizational competencies detached the importance of skills and competencies in both levels but not defining a specific expression for more important competencies. The integration of knowledge, skills, resources and their interrelation with personal and organizational objectives build indivisible competencies.

\section{Strategic Offshoring}

Two new strategic approaches, when properly combined, allow managers to leverage their companies' skills and resources well beyond the levels available with other strategies (Quinn \& Hilmer, 1994, p. 43): 
(...) concentrate the firm's own resources on a set of 'core competencies' where it can achieve definable preeminence and provide unique value for customers; and strategically outsource other activities - including many traditionally considered integral to any company - for which the firm has neither a critical strategic need nor special capabilities.

If supplier markets were totally reliable and efficient, rational companies would outsource everything except those special activities in which they could achieve a unique competitive edge, i.e., their core competencies (Quinn \& Hilmer, 1994). Most companies can benefit from extending outsourcing first in less critical areas - or in parts of activities, such as the payroll, for instance, rather than their entire accounting. As they gain experience, they may increase profit opportunities by outsourcing other activities.

The evolution of the business model and of process capability is becoming a mechanism for achieving strategic advantage in offshoring (Gupta \& Mukherji, 2007). The same idea is voiced by Aron and Singh (2005, p. 143): “... companies must treat offshoring as a strategic imperative if they wish to capture all its benefits".

Strategic management of outsourcing is perhaps the most powerful tool in management and the outsourcing of innovation is its frontier (Quinn, 2000). Research comparing outsourcing management as an innovation tool in Brazilian and Italian companies supports this statement (Gomes, 2007). Comments from JPMorgan Chase \& Co. (2007, p. 20) provide this firm's opinion about this item's importance henceforth:

Outsourcing of the repetitive and transaction-oriented personnel work is gaining increasing acceptance as a means of freeing up managerial bandwidth to focus on more strategic aspects of the HR function. We expect a secular trend of outsourcing - that which can be standardized as well as that which can be automated-in particular, anything that is common across organizations (that is, much of the HR function). What remains less clear is whether outsourcing will be done on a holistic basis or more opportunistically, using best-of-breed or integrated providers.

\section{EMerging Countries ANd Brazil as OffShoring Providers}

As services offshoring seems to start in the call center industry, it is important to look at call center costs. A typical call center budget allocation, based on the work of Anton (2005), indicates that the main cost consists of human resources $(64 \%)$. Therefore, reducing this item can improve the company's results substantially. $16 \%$ consists of IT costs and another $15 \%$ is consumed by telecommunications. Given that developing countries such as India, China and Brazil have lower wages than those of developed nations, offshoring is a good solution and an opportunity. Additionally, the observations of Taylor and Bain (2003) after Nasscom and McKinsey suggest that wages in India are $70-80 \%$ and $60-65 \%$ lower than in the UK and the US, respectively.

The studies of Batt, Doellgast and Kwon (2005, p. 2) showed that

Indian operations are more likely to use college educated workers while paying one-tenth of U.S. wages. But it is not a call center characteristic. China and others as OEM producers and India as English speaking service providers, especially IT, are now producing their own brands and products with quality and reliability and competing worldwide. So, emerging countries are learning how to produce and how to play the global game of international trade using their capabilities to be a good player.

The role of technology has evolved from providing support for corporations to transforming them. The ability to design, develop, implement and maintain advanced technology platforms and solutions to address business and customer needs has become a competitive advantage and a priority for 
corporations worldwide. The need for more dynamic technology solutions and the increased complexity, cost and risk associated with these technology platforms has created a growing need for specialists with experience in leveraging technology to help drive business strategy.

Gottfredson et al. (2005, p. 137) asked: "Should you always keep strategic capabilities within your walls? As globalization and technology transform more industries, all companies will eventually have to let go of that comfortable but simplistic guideline".

Since the start of offshoring, based on low cost, a tremendous evolution has materialized in emerging countries and in many cases, such as in telecommunications and IT infrastructure, an abundance of skilled people in many areas can be found in these countries. Thus, if the threat is increasing in the developed nations, opportunities are growing at the same pace for emerging countries.

India is always cited as a star in the offshoring of everything. Some of their companies reflect the truth of this image. Infosys, TCS and Wipro are examples with similar competencies; they yield above-average returns year after year. The Indian business environment is highly competitive and changes quickly. There are many consulting firms going into the country, such as Accenture and Deloitte Consulting, as well as divisions of large multinational technology firms, such as HP and IBM, IT outsourcing firms like EDS and Logica CMG, and software firms like Oracle and SAP. Speaking English is one of India's clear strengths.

According to the Dataquest India report published in October 2003, 75\% of the world's development centers assessed as being of Level 5 according to SEI-CMM were in India. SEI-CMM is the Carnegie Mellon Software Engineering Institute's Capability Maturity model, which assesses the quality of the processes and methodology of organizations' management system. Level 5 is the highest on this scale!

Boehe (2008) found that multinational corporations (MNC) can create competitive advantages in product developing using offshore insourcing process in combination with local outsourcing. According with these conclusions, high quality skills, capabilities and competencies are available in emerging countries and not only MNC can capture them; local companies can also do this and improve their competitive positions.

Currently, according to Infosys Technologies Limited (2006), eleven patent applications are pending in the U.S. Patent and Trademark Office and twenty four are pending in the Indian patent Office. This company's revenues grew from US\$545 million in 2002 to US $\$ 2.152$ billion in 2006 . The number of employees over this period soared from 10,700 to 52,700. This workforce includes employees of 59 nationalities recruited from a program with clearly defined criteria, in partnership with universities from India and from around the world. Regarding international certifications, the company has SEICMMI Level 5, CMM Level 5, PCMM Level 5, TL 9000 and ISO 9001-2000. As a typical offshoring company, its revenues come almost entirely from abroad (Table 2).

Table 2: Origin of Infosys Offshoring Revenues

\begin{tabular}{|c|c|c|c|}
\hline & 2004 & 2005 & 2006 \\
\hline North America & $71,2 \%$ & $65,2 \%$ & $64,8 \%$ \\
\hline Europe & $19,2 \%$ & $22,3 \%$ & $24,5 \%$ \\
\hline India & $1,3 \%$ & $1,9 \%$ & $1,8 \%$ \\
\hline Rest of the World & $8,3 \%$ & $10,6 \%$ & $8,9 \%$ \\
\hline Total & $100,0 \%$ & $100,0 \%$ & $100,0 \%$ \\
\hline
\end{tabular}

Source: Infosys Technologies Limited (2006)

TCS, another Indian star, is not very different from Infosys. Tata Consultancy Services [TCS], headquartered in Bombay, is one of India's largest companies, with more than sixty thousand employees, twenty-one thousand of whom were hired in 2006 (TCS, 2006). This workforce encompasses 53 nationalities. The company has operations in 35 countries, including Brazil. Its revenues in 2006 amounted to almost US\$3 billion and its average growth, from 2001 to 2006, was 
$34.3 \%$ a year. As for its revenues, 59\% come from the U.S., $22.5 \%$ from Europe, $6 \%$ from other countries and only $12.5 \%$ from the Indian market itself (First Global, 2006). The company is the IT solutions provider with the greatest enterprise-wide multiple certification in its field ever achieved (TCS, 2006).

Ongoing interaction with educational institutions continues to be a cornerstone of the company's strategy, in order to attract the best scientific and engineering talent and engage in cutting-edge research and development in partnership with universities. In January 2006 the Company entered a five-year R\&D collaboration program with Stanford University, among many institutions of higher education in the USA, the UK and Denmark (TCS, 2006).

However, how is Brazil faring in connection with the offshoring of services? Are we in good shape to provide them? How big is this kind of business for Brazilian companies? These questions lack complete answers. Though several cases were found in many sectors, there is no answer as to the extent to which Brazil is riding this wave.

In the Brazilian academic world, we found two papers presented at the last Enanpad event (2006): the first one related to offshoring call center services (Gião \& Oliveira, 2006), the other about two software developing companies (Sotto-Mayor \& Ferreira, 2006).

Since then, several cases have been (and continue to be) identified in formal or informal events and, following clarification of what the main concepts of offshoring are, some companies recognize themselves as offshoring service providers. Company A provides offshore services in English, French and Spanish through college level operators to many countries and intensive usage of VoIP. The types of services provided involve inbound and outbound sales, reservations, customer service and B2B applications. Company B provides English, Spanish and German operations and is one of the 50 largest call center enterprises in Brazil. Besides offshoring operations, during the Brazilian Carnival and year-end festivities, they provide 0800 multilingual support for tourists in Brazil.

Company $\mathrm{C}$ is a kind of $\mathrm{B} 2 \mathrm{~B}$ call center whose operators are people highly specialized in many areas, whose task is to help other companies in their relationship. Their main markets are Zone 1 countries and countries with about a 12-hour time difference such as China, Korea, Australia and India. They obtained these specialized operators through immigrant associations and have clients in China and Korea, speaking Mandarin and Korean. Company D, one of the world's biggest telecommunication manufacturers, has a managerial and maintenance expertise center in Brazil and can manage, update, and test any client network in any country in the world. The company has one other center in the world that is similar to Brazil's and both have competencies in the same areas, but the Brazilian one's budget is $40 \%$ lower than that of the other center. Company E, a car maker's R\&D center, provides projects, designs and services on demand from any of the company's plants around the world (United Nations Conference Trade and Development [UNCTD], 2005).

Thus, Brazil is a player in the offshoring services game. However, how big is this kind of business for companies established in this country? Of course, Brazil's share of this field is not as big as the Indian or Chinese portions, but Brazil is a player. But how many companies based in Brazil provide offshore services? Though that is not known, we hope that this article will be a catalyst for the identification of these companies.

\section{FinAL CONSIDERATIONS}

Services offshoring is unveiling new opportunities for developing countries. Providing services is easier than manufacturing, which requires putting plants in place. Where services are concerned, from call center positions to R\&D scientists, only simpler or highly specific facilities based on networked 
workstations are required in order to provide, develop, or manage services for any site in the world, and to do this faster. Alternatively, one can outsource to competent companies already in place.

It is a very new process in the business environment and one that arose out of a few instances in the early 90s, followed by a boom that continues to this day. This boom concerns not only the number of organizations engaged in offshoring but the transformation of an activity that originally concerned only the manufacturing process into one that also involves services, ranging from call centers and back-office operations to design and R\&D.

Figure 5 represents this offshoring evolution based on service complexity. Offshoring first started with low complexity services such as back-offices and call centers, low cost having been their chief driver.

\section{Figure 5: Offshoring Evolution Based on Service Complexity}

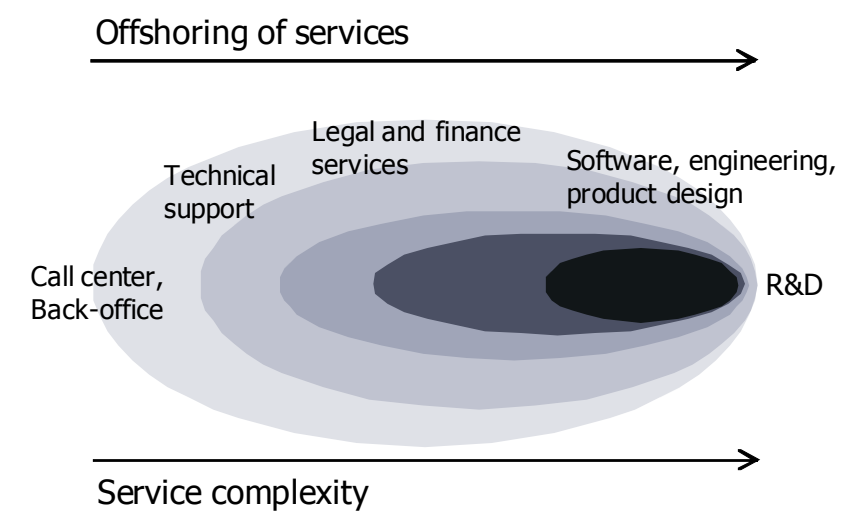

Source: the authors.

However, many companies now offshore highly complex activities, such as design and R\&D, the driver for this being not only low cost, but also a highly skilled workforce spread all over the world.

The effects upon the value chain are tremendous if one considers that most of it consists of services and if one also takes into account that core competencies are based on services and processes, rather than on resources. The underlying theory for services offshoring has some of its aspects anchored in the theories of strategy, international business or economics, but a new work is being published that addresses these issues from very different viewpoints, as follows.

First, one must ask what core competencies really consist of and why they should not be outsourced, if there is someone in the world that can do part of the job better, faster, and more cheaply. The second point is in part related to the first, but concerns innovations. If some of the company's activities are outsourced, why should the outsourcers be unable to produce innovations in their activities? With the fragmentation of the value chain, innovations can appear anywhere; why not use them to the company's benefit?

The third point involves a much more strategic analysis of the value chain based on outsourcing and offshoring perspectives. If at some point in the past the main objective of an organization was to dominate the entire value chain in order to achieve above average results, globalization broke the chain into very many segments and showed that competencies can be found anywhere in the world. From this point of view, parts of the value chain, especially those related to core competencies, can be provided in India, China, Singapore or Brazil. Of course, the control over patents, processes and activities needs to be improved and refined, but as a rule, organization can produce a better bottom line through offshoring.

The analysis presented in this paper is offered as an aid to systematic investigation involving value chains, core competencies, innovations and the accelerated process of offshore outsourcing of services. 
Some preliminary evidence showed countries and companies in good conditions to improve their participation in the international market. The internationalization of these new firms from emerging countries and their learning process may need extension to existing theories, at least from the perspective of emerging and in developing world.

Finally, India and its companies can be considered best-in-class where offshoring services is concerned and much of what they do can be replicated in other countries. Alliances between organizations and universities, language training, skilled people, government understanding and facilities, plus co-petition (cooperation combined with competition) among Brazilian based companies could help them build a cluster amounting to an offshoring structure, in order for them to compete worldwide and get a slice of these revenues that are floating around a borderless world. It is true that Brazil has many problems and differences between its regions, but the same is true of India, which does not consist only of Bangalore or Bombay. Yet India is the top-of-mind option when it comes to offshoring and the same could be true of Brazil. However, the first step is to find out: where are the Brazilian offshore service providers?

\section{REFERENCES}

Abramovsky, L., Griffith, R., \& Sako, M. (2004). Offshoring of business services and its impact on the UK economy. Advanced Institute of Management Research. Retrieved January 15, 2007, from http://www.aimresearch.org/uploads/pdf/Academic\%20Publications/offshoring\%20doc\%20_1.p df

Anton, J. (2005). Best-in-class call center performance: industry benchmark repor sample. Purdue University, USA. Retrieved December 10, 2006, from http://bmponlinestore.com/product_info.php?products_id=45

Aron, R., \& Singh, J. V. (2005). Getting offshoring right. Harvard Business, 83(12), 135-143.

Atkinson, R. (2004). Meeting the offshoring challenge. Progressive Policy Institute. Policy Report. July, 2004. Retrieved December 10, 2006, from http://www.ppionline.org/documents/offshoring2_0704.pdf

Bardhan A. D., \& Kroll, C. A. (2003). The new wave of outsourcing. Research Report. Fischer Center Research Report, University of California, Berkeley. Retrieved December 10, 2006, from http://papers.ssrn.com/sol3/papers.cfm?abstract_id=985741

Batt, R., Doellgast, V., \& Kwon, H. (2005). A comparison of service management and employment systems in U.S. and Indian Call Centers', offshoring white-collar work - the issues and implications. Washington, DC: Booking institution,

Boehe, D. M. (2008). In-house off-shoring of product development by MNCs. Brazilian Administration Review, 5(1), 1-18.

Datamonitor. (2007, Mach 05). Lloyds TSB returns Mumbai call center work to the UK - News. Retrieved December 10, 2006, from htp://www.datamonitor.com/industries/news/article/?pid=24792E80-8DFB-4A62-86573DB1564CCCA5\&type=NewsWire

Farrel, D. (2004). Beyond offshoring: assess your company's global potential. Harvard Business Review, 82(12), 82-90.

Feenstra, R., \& Hanson, G. (1996). Globalization, outsourcing, and wage inequality. The American Economic Review, 86(2), 240-245. 
Fleury, M. T. L., \& Fleury, A. (2002). Construindo o conceito de competência. Revista de Administração Contemporânea, 5(Edição Especial), 183-196.

Gião, P. R., \& Oliveira, M., Jr. (2006, setembro). Offshoring call centers for emerging markets: preliminary findings in Brazil. Anais do Encontro Nacional da Associação Nacional de PósGraduação e Pesquisa em Administração, Salvador, BA, Brazil, 30.

Gomes, C. (2007). Gestão de fontes externas de informação tecnológica e desempenho inovador na empresa. Tese de doutorado. Universidade de São Paulo, São Paulo, SP, Brazil.

Gottfredson, M., Puryear, R., \& Phillips, S. (2005). Strategic sourcing: from periphery to the core. Harvard Business Review, 83(2), 132-139.

Gottschalk, P., \& Solli-Saether, H. (2006). Managing successful IT outsourcing relationships. Hershey, USA: IRM Press.

Grossman, G., \& Rossi-Hansberg, E. (2006). Trading tasks: a simple theory of offshoring [Working Paper $\mathrm{N}^{\circ}$ W12721]. National Bureau of Economic Research. Princeton University. Retrieved November 06, 2006, from http://papers.ssrn.com/sol3/papers.cfm?abstract_id=948183

Gupta, A., \& Mukherji, S. (2007). Offhoring: the transition from economic drivers toward strategic global partnership and 24-hour knowledge factory. Journal of Electronic Commerce in Organizations, 5(2), 1-23. Retrieved November 06, 2007, from http://papers.ssrn.com/sol3/papers.cfm?abstract_id=938216

Hagel, J. III (2004). Offshoring goes on the offensive: cost cutting is only the first benefit. The McKinsey Quartely, (2), 21-29.

Hitt, M. A., Ireland, R. D., \& Hoskinsson, R. E. (2007). Strategic management: competitiveness and globalization concepts (7th. ed.). Mason, USA: Thomson South-Western.

Horvitz, A. (2004). Overview of market trends in offshoring: externalisation de services a l'international: opportunités \& risques. Conseillers du Commerce Extérieur de la France, France, McKinsey.

Infosys Technologies Limited. (2006). Annual Report 2005-2006. Infosys Technologies Limited, Bangalore, India. Retrieved November 06, 2006, from http://www.infosys.com/investors/reports-filings/annual-report/annual/Infosys-AR06.pdf

JPMorgan Chase \& Co. (2007, January 21). Computer services - HR \& Payroll outsourcing automating people processes - 2007 sector views. North America Equity Research. Retrieved January 15, 2007, from http://www.thomsononeim.com/v-hom.asp

Karmarkar, U. (2004). Will you survive the services revolution? Harvard Business Review, 82(6), 100-107.

Levine, L. (2004). Offshoring (a.k.a. offshore outsourcing) and job insecurity among U.S. workers. Congressional Research Service Report for Congress. Retrieved November 06, 2006, from http://fpc.state.gov/documents/organization/46688.pdf

Linder, J. C. (2004). Transformational outsourcing. MIT Sloan Management Review, 45(2), 52-58.

Lislie, C. (2003). Outsource a core competency? Why private equity groups are outsourcing business strategy due diligence. The Journal of Private Equity, 7(1), 72-75. 
Lynn, L., \& Salzman, H. (2005, June). The 'new' globalization of engineering: how the offshoring of advanced engineering affects competitiveness and development. European Group for Organizational Studies Colloquium, Berlin, 21. Retrieved November 06, 2006, from http://www.urban.org/UploadedPDF/411226_new_globalization.pdf

Moori, R. G., \& Zilber, M. A. (2003). Um estudo da cadeia de valores com a utilização da análise fatorial. Revista de Administração Contemporânea, 7(3), 127-147.

Patki, T., \& Patki, A. (2007). Innovative technological paradigms for corporate offshoring. Journal of Electronic Commerce in Organizations, 5(2), 57-76.

Porter, M. (1990). The competitive advantage of nations. Harvard Business Review, 68(2), 73-91.

Porter, M. (1998). Competitive advantage: creating and sustaining superior performance. New York, USA: The Free Press.

Prado, E. P. V., \& Takaoka, H. (2002). Os fatores que motivam a adoção da terceirização da tecnologia de informação: uma análise do setor industrial de São Paulo. Revista de Administração Contemporânea, 6(3), 129-147.

Prahalad, C., \& Hamel G. (1990). The core competence of the corporation. Harvard Business Review, 68(3), 79-91.

Quinn, J. (1999). Strategic outsourcing: leveraging knowledge capabilities. MIT Sloan Management Review, 40(4), 9-21.

Quinn, J. (2000). Outsourcing innovation: the new engine of growth. MIT Sloan Management Review, 41(4), 13-28.

Quinn, J., Doorley, T., \& Paquette, P. (1999). Technology in services: rethinking strategic focus. MIT Sloan Management Review, 31(2), 79-87.

Quinn, J., \& Hilmer, F. (1994). Strategic outsourcing. MIT Sloan Management Review, 35(4), 43-55.

Ramanujan, S., \& Sandhya, J. (2006). A legal perspective on outsourcing and offshoring. Journal of American Academy of Business, 8(1), 51-58.

Robinson, M., \& Kalakota, R. (2004). Offshore outsourcing: business models, ROI and best practices (2nd ed.). Alpharetta, USA: Mivar Press, Inc.

Reid, G. (2003). Free trade, business strategy and globalization. University of St. Andrews, Scotland. Retrieved December 18, 2006, from http://www.st-andrews.ac.uk/crieff/papers/dp0009.pdf

Sako, M. (2005, November). Outsourcing and offshoring: key trends and issues. Oxford Said Business School. Retrieved December 18, 2006, from http://brie.berkeley.edu/conf/Sako.pdf

Sotto-Mayor, L., \& Ferreira, G. (2006, setembro). Internacionalização de empresas de prestação de serviços em tecnologia de informação: o estudo de caso de duas empresas brasileiras. Anais do Encontro Nacional da Associação Nacional de Pós-Graduação e Pesquisa em Administração, Salvador, BA, Brasil, 30.

Tata Consultancy Services. (2006). Nurturing ideas, driving growth: annual report 2005-2006. Bombaim, India. Retrieved December 18, 2006, from http://www.tcs.com/investors/Documents/Annual\%20Reports/TCS_AnnualReport_FY2006.PDF

The Wall Street Journal. (2002, November 7). Indian software companies raid U.S. turf. p. B.6.

Taylor, P., \& Bain, P. (2003). Call centres in scotland and outsourced competition from India. Report for Scottish Development International. Scotecon Network. University of Stirling. Retrieved 
December 18, 2006, from http:// www.scotecon.net/publications/Call\%20Centres\%20Scotland.pdf

United Nations Conference Trade and Development. (2005). World investment report 2005: transnational corporations and the internationalization of $R \& D$. United Nations. Retrieved December 18, 2006, from http://www.worldinvestmentreport.org/

Vasconcelos, F. C., \& Cyrino, A. B. (2000). Vantagem competitiva: os modelos teóricos atuais e a convergência entre estratégia e teoria organizacional. Revista de Administração de Empresas, 40(4), 20-37.

Vashistha, A., \& Vashistha, A. (2006). The offshore nation: strategies for success in global outsourcing and offshoring. New York, USA: McGraw-Hill. 